\title{
The Impact of Water Quality on Beef Cattle Health and Performance ${ }^{1}$
}

Megan N. Brew, Jeffrey Carter, and Mary K. Maddox ${ }^{2}$

\section{Introduction}

Important for the transport of nutrients between cells and as a vital medium for intracellular metabolism, water is the most abundant component in all living organisms. In fact, the typical body composition of an adult mammal contains about $60 \%$ water. When listing the nutrient needs of beef cattle, water is often added only as an afterthought. Despite its low profile, water may be the most important nutrient of all. Indeed water is needed for body temperature regulation and the digestion, absorption, and utilization of all other nutrients; water plays an essential role in every life process. Beef cattle need regular access to clean drinking water in order to experience optimum health. Research has demonstrated a positive relationship between access to clean drinking water and performance factors such as growth, reproduction, and milk production.

Animals that drink clean, contaminant-free water are generally less prone to illness and disease, gain more weight, and produce more milk. Producers have a great deal of control over both the quantity and quality of water that is provided to animals. Monitoring water quality and observing best management practices (BMPs) for water management are inexpensive yet effective ways to improve overall animal performance.

\section{Common Contaminants of Drinking Water}

Livestock drinking water may be contaminated by a number of factors including minerals (total dissolved solids, or TDS), manure, microorganisms, and algae. These contaminants can impact the appearance, odor, and taste of drinking water as well as its physical and chemical properties. See Figures 1 (fountain), 2 (tank), and 3 (pond) and compare those photos with data found in Table 1 to see how appearance and measurable quality characteristics correlate. Some contaminants may directly impact animal health by causing disease and infection; others have a more indirect effect and may cause cattle to decrease their overall water intake. When water intake is suppressed, feed intake will also decrease, and, as a result, animals will gain less weight. Livestock can survive for as long as sixty days with little or no food, but only seven days without water. In sub-tropic, hot climates like Florida, that number may be even less.

1. This document is AN187, one of a series of the Animal Science Department, Florida Cooperative Extension Service, Institute of Food and Agricultural Sciences, University of Florida. Original publication date November 2008. Visit the EDIS Web Site at http://edis.ifas.ufl.edu.

2. Megan N. Brew, extension agent; Jeffrey Carter, assistant professor of Animal Science; and Mary K. Maddox, biological scientist; Department of Animal Sciences, Florida Cooperative Extension Service, Institute of Food and Agricultural Sciences, University of Florida, Gainesville, FL.

The Institute of Food and Agricultural Sciences (IFAS) is an Equal Opportunity Institution authorized to provide research, educational information and other services only to individuals and institutions that function with non-discrimination with respect to race, creed, color, religion, age, disability, sex, sexual orientation, marital status, national origin, political opinions or affiliations. U.S. Department of Agriculture, Cooperative Extension Service, University of Florida, IFAS, Florida A. \& M. University Cooperative Extension Program, and Boards of County Commissioners Cooperating. Larry Arrington, Dean 
When the mineral content of water exceeds safe levels, animal performance can suffer. High levels of sodium (salt) depress water intake and result in weight loss and diarrhea. Animals exposed to water that is high in sulfur have increased incidences of polioencephalomacia (PEM) and experience higher mortality rates. Salinity of water, the concentration of dissolved salts in water, can be expressed as either TDS or TSS (Total Soluble Salts), which is also known as electrical conductivity (EC). Therefore, TDS and conductivity results presented in Table 1 are complementary. Electrolytes, or ions that regulate or affect metabolic processes, such as magnesium $(\mathrm{Mg}+)$, calcium $(\mathrm{Ca}+)$, sodium $(\mathrm{Na}+)$, and chloride (Cl-), contribute to the salinity of water. At certain high levels, these electrolytes can cause toxic effects by themselves or by interfering with the absorption of other important nutrients. Alone, TDS, TSS, or even EC tell us little about the quality of any water sample. However, these are benchmarks that when elevated give us a clue that some minerals may merit further and more precise analysis.

Manure is a common contaminant in cattle drinking water, particularly when the primary source of water is a pond where cattle may spend a good deal of time loitering. Manure is carried into drinking water on the cattle's hooves and is deposited directly when the animals defecate. Livestock drinking water that is contaminated with manure can become a hotspot for bacterial growth, which in turn can cause animal disease. High levels of bacteria have been found in cattle watering ponds where they may contribute to outbreaks of coliform related illnesses caused by E. coli, E. aerogenes, and Klebsiella species. These can lead to mastitis, urinary tract infections, diarrhea and numerous other unsavory and often lethal infections.

Fecal contamination of livestock drinking water can cause algae blooms through a process known as nutrient loading, or eutrophication. Blue-green algae are common contaminants in standing water. When ponds become overgrown with algae, cattle will avoid drinking from them in favor of other water sources, if any exist. If no other source of fresh drinking water is available, they will decrease their overall water intake, which results in poorer performance. In addition to blue-green algae, other water-borne microbes can negatively impact animal health. Leptospirosis, which causes reproductive loss in cows, is spread by a microorganism found in water contaminated by urine. The soil-borne microbe believed to be primarily responsible for foot $\operatorname{rot}(F$. necrophorum) can also be spread by consumption of contaminated water.

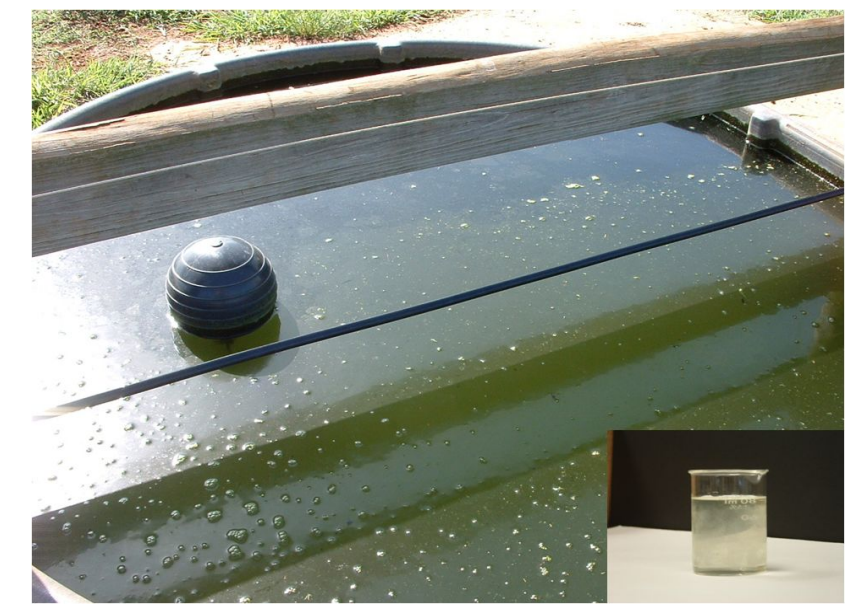

Figure 1. Tank watering system and photo (inset) of water sample.

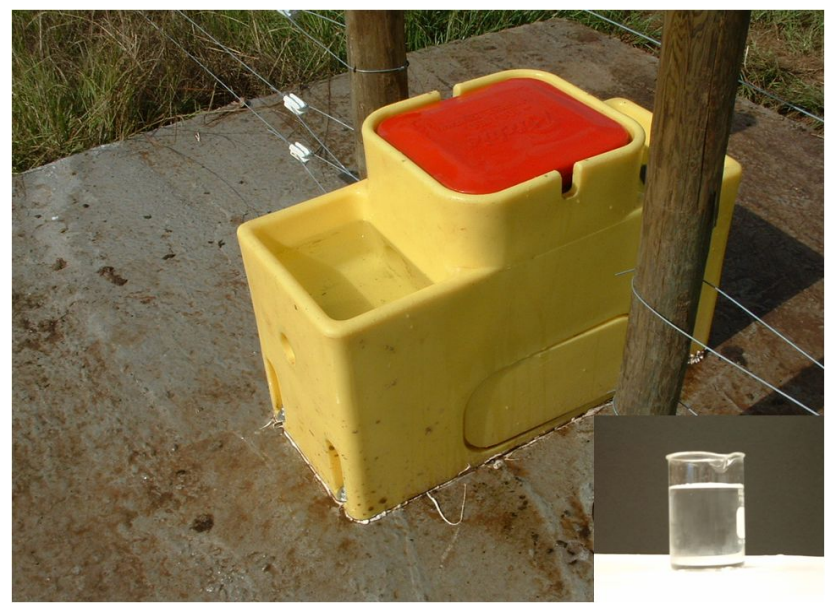

Figure 2. Fountain watering system and photo (inset) of water sample.

\section{Evaluation of Drinking Water Management Practices}

Cattle producers have the opportunity to enhance animal health and performance by improving the quality of water offered to their animals. Small changes in water management may result in improved performance, as well as financial gains 


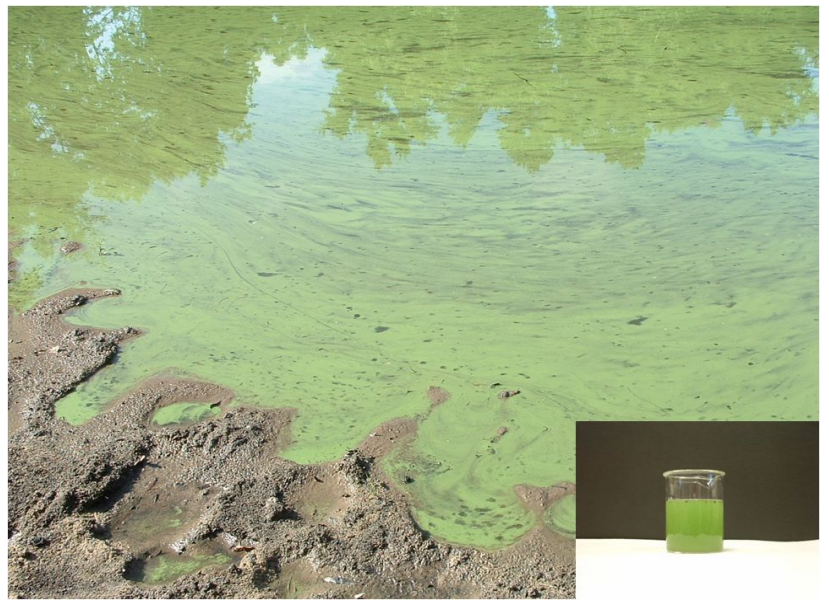

Figure 3. Pond watering system and photo (inset) of water sample

associated with decreased potential for illness and disease.

The first step in improving water quality is to do a thorough evaluation of your current situation. Following are some tips to help guide the development of your on-farm protocol for water quality:

- Is water offered in adequate quantity for the number and type of animals on your property? At least two feet of accessible linear water space is needed per 10 head of cattle.

- Are watering devices spaced appropriately and located away from stream banks? Watering devices should be easily accessible by animals. Strategic placement of watering devices can influence grazing, compaction, and nutrient deposition patterns.

- Is water offered fresh or from a pond? Recent research has shown that heifers with access to water pumped from a well or spring gained $23 \%$ more weight than heifers drinking pond water.

- How often are watering devices cleaned? Increasing the frequency of cleaning may improve milk production in brood cows.

As part of the evaluation process, it may be useful to have the water on your property tested for contaminants. Your county extension agent can help you develop a testing plan and identify an appropriate laboratory. You may also refer to Mylavarapu and
Kennelley (http://edis.ifas.ufl.edu/SS184) for complete information on sample collection and testing fees. Once any problems are identified, steps can be taken to improve them. Evaluate water quality regularly in order to ensure a constant supply of high quality drinking water.

\section{Conclusion}

The quality of drinking water provided to beef cattle can have a significant impact on animal health and performance. Reducing the concentration of TDS, blue-green algae and other microorganisms, preventing fecal contamination, providing fresh rather than pond water and cleaning watering devices regularly can all result in measurable improvements in beef cattle health and performance.

\section{References}

Bagley, C.V., J. Kotuby-Amacher, and K. Farrell-Poe. 1997. Analysis of water quality for livestock. Utah State University, Animal Health Fact Sheet AH/Beef/28.

Church, D.C., and W.G. Pond. 1974. Introduction to nutrition. In: Basic animal nutrition and feeding, $3^{\text {rd }}$ Ed. John Wiley \& Sons, Inc., New York.

Coffee, C.J. 1998. The cell: The fundamental unit of metabolism. In: Metabolism. Fence Creek Publ., LLC., Madison, CT.

Ensley, S.M. 2000. Relationship of drinking water quality to production and reproduction in dairy herds. PhD dissertation, Iowa State University.

Fraser, C.M., J.A. Bergeron, A. Mays, and S.E. Aiello. 1991. The Merck Veterinary Manual, $7^{\text {th }}$ Ed. Merck \& Co., Inc., Rahway, NJ.

LeJeune, J.T., Besser, T.E., Merill, N.L., Rice, D.H., and D.D. Hancock. 2001. Livestock drinking water microbiology and the factors influencing the quality of drinking water offered to cattle. J. Dairy Sci. 84:1856-1862. 
McDowell, L.R. 1985. Nutrition of grazing ruminants in warm climates. Academic Press, N.Y.

McDowell, L.R., and J.D. Arthington. 2005. Minerals for grazing ruminants in tropical regions. University of Florida /IFAS, Gainesville, FL.

McFarland, D.F. 1998. Watering dairy cattle in Proceedings of Dairy Feeding Systems:

Management, Components, and Nutrients, NRAES, Ithaca, NY.

Mylavarapu, R.S., and E. Kennelley. 2005. Water test information sheet. University of Florida /IFAS Extension Electronic Data Information Service. (http://edis.ifas.ufl.edu/SS184).
Patterson, H.H., Johnson, P.S., and W.B. Epperson. 2003. Effect of total dissolved solids

and sulfates in drinking water for growing steers. Proceedings, Western Section, American Society of Animal Science. Vol 54

Willms, W.D., Kenzie, O.R., and T.A. McAllister. 2002. Effects of water quality on cattle performance. Journal of Range Management $55: 452-460$.

Wright, C.L. 2007. Management of water quality for beef cattle. Veterinary Clinics of North America: Food Animal Practice. 23:91-103.

Table 1. Water Analysis Report from Three Different Sources

\begin{tabular}{|c|c|c|c|c|c|}
\hline Nutrient $^{1}$ & Fountain & Tank & Pond & Limits $^{2}$ & $\begin{array}{c}\begin{array}{c}\text { Critical levels } \\
(\%)^{3}\end{array} \\
\end{array}$ \\
\hline Nitrate $\mathrm{N}$ & 3.3 & 1.2 & 8.3 & $<100.0$ & --- \\
\hline Phosphorus & 0.1 & 0.9 & 0.04 & --- & $0.19-0.73$ \\
\hline Calcium & 15.6 & 36.1 & 75.4 & --- & $0.12-0.34$ \\
\hline Magnesium & 1.5 & 1.8 & 1.7 & --- & 0.10 \\
\hline Sodium & 14.6 & 3.6 & 2.5 & --- & $0.06-0.08$ \\
\hline Chloride & 19.0 & 22.0 & 13.0 & --- & $0.10-0.20$ \\
\hline Sulfate & 14.5 & 1.4 & 1.5 & $<500.0$ & $0.10-0.32$ \\
\hline $\mathrm{pH}$ & 7.1 & 7.0 & 7.4 & & --- \\
\hline Conductivity $^{4}$ & 0.1 & 0.2 & 0.4 & --- & -- \\
\hline $\begin{array}{l}\text { Total Dissolved } \\
\text { Solids (TDS) }\end{array}$ & 89.6 & 145.9 & 238.7 & $<1000.0$ & -- \\
\hline \multicolumn{6}{|c|}{${ }^{1}$ Unless otherwise indicated, all values expressed as parts per million (ppm). } \\
\hline \multicolumn{6}{|c|}{${ }^{2}$ Established in Bagley et al. (1997); values less than those stated are optimal. } \\
\hline \multicolumn{6}{|c|}{$\begin{array}{l}{ }^{3} \text { Establsihed in McDowell (1985) and further reported in McDowell and Arthington (2005); these are minimum } \\
\text { levels based on animal nutrient requirements most of which is provided by forage or other feedstuffs. }\end{array}$} \\
\hline
\end{tabular}

